\title{
The Levels Of Questions Used In The English Textbook Entitled "Stop Bullying Now"For The Xi Grade Of Senior High School
}

\author{
K.B Wahyuni ${ }^{1 *}$ (D) \\ ${ }^{1}$ English Language Ganesha University of Education, Bali, Indonesia
}

\section{A R T I C L E I N F O}

Article history:

Received May 10, 2021

Revised May 12, 2021

Accepted July 09, 2021

Available online August 25, 2021

Kata Kunci:

Pemahaman bacaan; berpikir kritis; Taksonomi Barrett

Keywords:

Reading comprehension; Critical thinking; Barrett's Taxonomy

DOI:

http://dx.doi.org/10.23887/jpbi.v9i2. 34393

\begin{abstract}
A B S T R A K
Pemahaman membaca pada siswa Indonesia sangat lemah. Terbukti dengan Pisa 2018, hasil yang menyatakan bahwa dari perbandingan antara IPA, matematika dan pemahaman bacaan, siswa Indonesia berada di peringkat 74 di urutan keenam dari bawah. Penelitian ini bertujuan untuk menganalisis tingkat pertanyaan yang digunakan dalam buku teks bahasa Inggris berjudul "Stop Bullying Now" untuk kelas XI SMA yang diterbitkan oleh Kementerian Pendidikan dan Kebudayaan Republik Indonesia tahun 2017. Analisis ini menggunakan taksonomi Barrett untuk menguji pemahaman bacaan. pertanyaan dalam buku dengan analisis isi penelitian kualitatif. Ada lima tingkatan pertanyaan pemahaman bacaan berdasarkan taksonomi Barrett, yaitu pemahaman literal, reorganisasi, inferensial, evaluasi, dan apresiasi. Hasil penelitian menunjukkan bahwa tingkat pemahaman literal $(7,45 \%)$, reorganisasi (0\%), inferensial $(39,36 \%)$, evaluasi $(36,17 \%)$ dan apresiasi $(17,02 \%)$. Hal ini menunjukkan bahwa pemahaman tingkat tinggi masih dominan daripada tingkat yang lebih rendah tetapi tingkat tidak menyebar merata di semua teks. Hasil penelitian ini dapat memberikan gambaran tentang tingkat pertanyaan pemahaman bacaan yang digunakan dalam buku teks bahasa Inggris yang berjudul "Stop Bullying Now" yang berguna bagi guru sebagai panduan dalam mempelajari pemahaman bacaan bahasa Inggris.
\end{abstract}

\section{A B S T R A C T}

Reading comprehension in Indonesian students is very weak. It is proven by Pisa 2018, a result which states that from a comparison between science, mathematics, and reading comprehension, Indonesian students are ranked 74th in the sixth from bottom. This article aims to analyze the level of questions used in an English textbook entitled "Stop Bullying Now" for class XI SMA published by the Ministry of Education and Culture of the Republic of Indonesia in 2017. This analysis uses Barrett's taxonomy to test reading comprehension. Questions in the book with content analysis of qualitative research. Based on Barrett's taxonomy, there are five levels of reading comprehension questions: literal comprehension, reorganization, inferential, evaluation, and appreciation. The results showed that the level of literal understanding $(7.45 \%)$, reorganization $(0 \%)$, inferential (39.36\%), evaluation (36.17\%), and appreciation (17.02\%). This shows that the higher-level comprehension is dominant over lower-level comprehension, but the level is not evenly distributed in all texts. The results of this study can provide an overview of the level of reading comprehension questions used in the English textbook entitled "Stop Bullying Now," which is helpful for teachers as a guide in learning English reading comprehension.

This is an open-access article under the CC BY-SA license. Copyright $(2021$ by Author. Published by Universitas Pendidikan Ganesha.

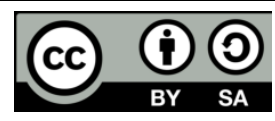

\section{INTRODUCTION}

Since the 2013 curriculum, students are expected to be able to think critically in all subjects, especially in reading skills (Purwanita et al., 2019). Critical thinking is the ability that is emphasized in 21 st-century skills. There are four learning of 21 st-century skills namely, critical thinking skills, communication skills, collaboration skills, and creativity skills (Kembara et al., 2018; Silberman et al., 2021). Critical thinking refers to the student's ability to analyze and make a choice with a complex problem in the text. 21st-century skills can help students in the learning process and are needed for the development of a world that will continue to change (McNamara et al., 2020; Mutakinati \& Anwari, 2018). Critical thinking is a higher-order thinking skill that every human being has. Higher-order thinking skills are skills that go beyond basic observation of facts and memorizing a problem. Higherorder thinking skills, namely being someone who has high creativity, innovative and evaluative (Din, 2020; Moghadam et al., 2021). Curriculum 2013 is designed to improve students to be able to compete in the 21 st century.

However the students' critical thinking is still low (Aufa et al., 2021; Crismono, 2017). Based on preliminary studies conducted in the English education department in Universitas Islam Negeri Hidayatullah Jakarta, most of the lecturers criticized students regarding their reading comprehension skills. This has been proven 
by the low reading comprehension ability of students. The students' reading comprehension score is low because the test uses the High Order Thinking Skill. Most of the questions used are texts that require critical thinking to test their reason for a case. In this case, if students do not understand the reading, students will have difficulty answering questions. This shows that students' ability to think at higher levels is still not satisfactory (Mutakinati et al., 2018; Turan \& Koç, 2018). The situation above is in line with the results of the PISA study released by the OECD. The results of the study show that the reading comprehension of students in Indonesia only reaches an average score of 371, with the OECD average score of 487 (Hewi \& Shaleh, 2020; Nugrahanto \& Zuchdi, 2019). This study has assessed 600,000 children aged 15 years from 79 countries every three years. From the comparison between students' mathematics, science, and reading comprehension abilities, Indonesia is ranked 74th in sixth place from the bottom for the reading comprehension category. Based on the result, Indonesian students have low reading comprehension skills (Halawa et al., 2020).

Reading comprehension must be honed from an early age because understanding a writer's message for readers is not easy (Fathiara et al., 2019; Laily \& Naqiyyah, 2014). However, most students have difficulty understanding a passage (Fathiara et al., 2019; Yunita et al., 2017). Therefore, it requires high-level thinking in students to understand a reading text. In response to this, there must be strong evidence to measure the level of reading comprehension in students by analyzing students' reading comprehension level questions on reading textbooks using Barrett's Taxonomy (Christianti, 2013; Darnis, 2018). Reading comprehension questions is important for learning to make students achieve their learning goals. The habit of understanding reading is one way to develop critical thinking and will improve students' reading skills (Herliana \& Anugraheni, 2020; Pramesti, 2018). By analyzing the level of reading comprehension questions, the teacher will find out whether students are already thinking critically or are still thinking at a low level. Students-initiated questioning had a significant positive effect on the student's questioning skills and reasoning (Widyaningrum \& Hasanudin, 2019).

The schools conduct seminars in all subjects on reading comprehension levels based on Barrett's taxonomy (Creed et al., 2012; Hashimoto et al., 2019). Thus, it is hoped that teachers can help improve competence in asking questions and checking reading comprehension through reading texts. Reading comprehension questions help the student to think critically (Aufa et al., 2021; Moghadam et al., 2021). Higher-order thinking skills are applied in the learning process to make questions for students (Arsy et al., 2020; Mutakinati et al., 2018). But most of the answers to reading comprehension questions in books always follow the text. Students can answer easily because literal understanding can be answered without critical thinking. So the question arises, does the correct answer shows that students understand the reading text? On the other hand, does the wrong answer indicate the student does not understand the reading text? In checking reading comprehension, the question raises how the teacher can find reading comprehension questions that can help students understand the text? Can reading comprehension questions help students to talk about their opinions related to the reading topic? And, what nature of reading comprehension questions should students ask? The various questions above require a pragmatic approach which refers to the application of HOTS in all subjects in schools, especially questions of reading comprehension. Reading comprehension questions must comply with curriculum policies that are in line with the HOTS issue. It can be concluded that the low level of HOTS can affect the students' low ability to understand texts (Pratama \& Retnawati, 2018; Sagala \& Andriani, 2019).

The lack of a formal definition of higher-order thinking mentions the fact that there is no general definition of the educational literature. High-level thinking is also called critical thinking (Ichsan et al., 2019; Tanudjaya \& Doorman, 2020). Critical thinking is the most important and the broader component of higher-order thinking (HOTS). Teachers need to plan assessments in students' skills in analyzing, critical thinking, creative thinking, problem-solving, and evaluation (Adadan \& Oner, 2018; Le et al., 2019). There are three categories of high-level thinking, namely, Transfer, Problem solving, and Critical thinking. From this statement, HOTS needs to be built based on critical thinking and problem-solving (Pratama \& Retnawati, 2018; Sagala \& Andriani, 2019). Based on the 2013 National Curriculum, the English textbook entitled "Stop Bullying Now" for XI Grade of Senior High School" is one of the books published by the Indonesian Ministry of Education and Culture (MECI) prepared by the government to implement the 2013 curriculum. This is an English book as a medium to support students' reading comprehension to improve reading skills. (Majid et al., 2012; Pratama \& Retnawati, 2018) The publisher provided the book to support teachers and students in the learning process. So, this study uses this book entitled "Stop Bullying Now" for XI Grade of Senior High School to analyze the level of questions based on Barrett's Taxonomy because this book is published by the Ministry of Education and Culture (MECI). Besides, this book is used by teachers in the learning process. In addition, the book "Stop Bullying Now" was chosen for analysis because it has fulfilled 5 aspects of the assessment such as Practical Considerations, Layout, and Design, Activities, Language Type, Subjects, and Content. Besides, the suitability of this book in terms of content and presentation is determined by the BSNP which has good quality. Previous research findings stated that the book "Stop Bullying Now" is a good book category (Cahya et al., 2020; Pakpahan et al., 2021). So, by achieving an average score of 90 percent of the ten proposed criteria, this book is recommended for analysis. 
Based on the problem above, this study aims to analyze the levels of questions used in the English textbook entitled "Stop Bullying Now" for the XI grade of Senior High School". This book was chosen because it is published by the Ministry of Education and Culture of Indonesia which must be following HOTS questions. The researcher was interested in researching the English textbook entitled "Stop Bullying Now" for the XI Grade of Senior High School". In this study, taking all reading comprehension questions in the book based on the passage of the text. There are five analysis uses reading comprehension levels based on Barrett's taxonomy, namely (1) literal comprehension (2) reorganization comprehension, (3) inferential comprehension, (4) evaluation comprehension, and (5), appreciation comprehension. The comprehension level statement aims to check the level of reading comprehension questions and determine the suitability of questions from higher-order thinking. So, the researcher determines the level comprehension question based on Barrett's taxonomy.

\section{METHOD}

This analysis uses descriptive analysis with content analysis. The data were taken by purposive sampling from the English textbook entitled "Stop Bullying Now" for the XI grade of Senior High School. This subject of this study was a nonparticipation observer because this research only documents ". Document analysis is used to complement the checklist method in qualitative research. This analysis focuses on all reading comprehension questions in the book based on the passage of reading text. This researcher analyzed the data by checklist form with gave code based on categorizing of five levels of Barrett's taxonomy. There are 5 text types namely analytical exposition, descriptive, explanation, narrative, hortatory exposition, and narrative. So, by checklist, the researcher found the data.

\section{RESULT AND DISCUSSION}

\section{Result}

Dealing with the research reading comprehension questions which have been explained, the researcher provides the results of reading comprehension questions in the students' book. The results of the data obtained showed that the inferential level (37) was dominated by all reading comprehension questions in the English textbook. The reading comprehension question in the book does not spread evenly. The second dominated was the evaluation comprehension question (34). The levels of questions based on Barrett's taxonomy are literal, reorganization, inferential, evaluation, and appreciation comprehension. Based on the data, inferential was dominated in each text reading.

Table 1. Specification of Reading Comprehension Questions in the English Textbook Entitled

\begin{tabular}{|c|c|c|c|}
\hline Reading Sub-Skills & $\begin{array}{l}\text { Questions } \\
\text { Levels }\end{array}$ & $\begin{array}{l}\text { Questions } \\
\text { Format }\end{array}$ & $\begin{array}{l}\text { Number } \\
\text { Of items }\end{array}$ \\
\hline $\begin{array}{l}\text { Identify main facts, details, sequence, events, } \\
\text { comparison, cause and effect relationships, and traits in } \\
\text { the reading text that stated explicitly }\end{array}$ & $\begin{array}{l}\text { Literal } \\
\text { Comprehension }\end{array}$ & $\begin{array}{l}\text { Open-ended } \\
\text { question }\end{array}$ & 7 \\
\hline $\begin{array}{l}\text { Organize ideas or information in the reading text into an } \\
\text { outline that is stated explicitly. }\end{array}$ & $\begin{array}{l}\text { Reorganization } \\
\text { Comprehension }\end{array}$ & $\begin{array}{l}\text { Open-ended } \\
\text { question }\end{array}$ & 0 \\
\hline $\begin{array}{l}\text { Drawing inferences of main ideas, comparison, supporting } \\
\text { details, cause and effect relationship from the context }\end{array}$ & $\begin{array}{l}\text { Inferential } \\
\text { Comprehension }\end{array}$ & $\begin{array}{l}\text { Open-ended } \\
\text { question }\end{array}$ & 37 \\
\hline $\begin{array}{l}\text { Making evaluative judgment from evaluative thinking on ideas } \\
\text { provided in the reading text }\end{array}$ & $\begin{array}{l}\text { Evaluation } \\
\text { Comprehension }\end{array}$ & $\begin{array}{l}\text { Open-ended } \\
\text { question }\end{array}$ & 34 \\
\hline Expressing emotional response to the reading text & $\begin{array}{l}\text { Appreciation } \\
\text { Comprehension }\end{array}$ & $\begin{array}{l}\text { Open-ended } \\
\text { question }\end{array}$ & 16 \\
\hline
\end{tabular}

Table 1 shows that the reading sub-skills have met the five levels of Barrett taxonomy. However, all question formats are designed as open questions and do not vary. In addition, the question level is not balanced because the middle level, namely inferential comprehension, dominates in each reading comprehension question. Therefore, the reading comprehension questions in level in the English Textbook Entitled "Stop Bullying Now" for XI Grade of Senior High School are only part of the questions that are in accordance with the national curriculum. Based on the analysis of the data obtained literal and reorganization include lower level categorized. Inferential, evaluation, and appreciation include higher-level categories. The result shows that lower-level (7, 45 
$\%)$, and higher-level (92,55 \%), Higher level are dominated in the English Textbook Entitled "Stop Bullying Now" for XI Grade of Senior High School". This book is already in accordance with the curriculum national.

There are 7 reading comprehension constructed at the level of literal comprehension. Literal comprehension questions are ideas and information that are explicitly stated in the text. This question is very easy to construct because it is too quick and easy to find answers. Although literal questions are easy to construct, this level is fewer questions than others. The questions that ask students to determine details, sequences, and comparisons are not found in this book. Table 2 shows that some examples of literal comprehension questions.

Table 2. Example of Literal Comprehension Question (recognition)

\begin{tabular}{|c|c|c|c|}
\hline No & Questions & Features of Descriptor & Unit \\
\hline 1 & What is global warming? & Recognition of Main Idea & Chapter 4 \\
\hline 2 & $\begin{array}{l}\text { Why are earthquakes considered as the most deadly } \\
\text { natural hazards? }\end{array}$ & $\begin{array}{l}\text { Recognition of Cause and } \\
\text { Effect }\end{array}$ & Chapter 8 \\
\hline 3 & What happened at the end of the story? Please describe. & Recognition of Main Idea & Chapter 8 \\
\hline 4 & $\begin{array}{l}\text { Why did the fisherman's wife keep asking her husband } \\
\text { to go back to the fish? }\end{array}$ & $\begin{array}{l}\text { Recognition of Cause and } \\
\text { Effect }\end{array}$ & Chapter 8 \\
\hline 5 & Why did President Sukarno want everyone to be united? & $\begin{array}{l}\text { Recognition of Cause and } \\
\text { Effect }\end{array}$ & Chapter 8 \\
\hline
\end{tabular}

There was not a single question related to reorganization questions. Reorganization is a level of questions that ask students to classify, synthesize, describe, and summarize. The reorganization level question is not difficult to construct, however, the reorganization question is not found in the English Textbook Entitled "Stop Bullying Now" for XI Grade of Senior High School". Based on three explanations of inferential, namely predicting outcomes, inferring, and interpreting figurative language, there are 37 reading comprehension questions built at the inferential level. However, questions that ask students to predict outcomes, inferring sequence, and inferring character traits were not found in the English Textbook Entitled "Stop Bullying Now" for XI Grade of Senior High School". Table 3 shows that some examples of inferential comprehension questions.

Table 3. Example of inferential comprehension question

\begin{tabular}{|c|c|c|c|}
\hline No & Questions & Features of Descriptor & Unit \\
\hline 1 & Is it a severe problem? Why? & $\begin{array}{l}\text { Inferring Cause and } \\
\text { Effect Relationship }\end{array}$ & Chapter 4 \\
\hline 2 & Is this an inspiring song? Does it inspire you? & Inferring Supporting Detail & Chapter 7 \\
\hline 3 & $\begin{array}{l}\text { Invictus is a Latin word that means unconquered. } \\
\text { What does it say about the poem? }\end{array}$ & $\begin{array}{l}\text { Inferring about } \\
\text { Figurative Language }\end{array}$ & Chapter 7 \\
\hline 4 & $\begin{array}{l}\text { Ki Hajar Dewantara has had a great impact on } \\
\text { the Indonesian struggle for freedom, and } \\
\text { especially education. Discuss with your peers what } \\
\text { may have been different if he had not been there. }\end{array}$ & Inferring the Main Idea & Chapter 8 \\
\hline 5 & $\begin{array}{l}\text { Can you find any similarities between } \\
\text { Ki Hajar Dewantara and yourself? Describe }\end{array}$ & Inferring Comparison & Chapter 8 \\
\hline
\end{tabular}

There are 34 reading comprehension constructed in the level of evaluation comprehension. Evaluation is a question that encourages students to make assessments using experience, value knowledge, and written references. Evaluation level questions are not very complex to construct. But questions of this level are not very domineering. Not even all level of evaluation questions are in the English Textbook Entitled "Stop Bullying Now" for XI Grade of Senior High School”. For example on questions of the judgment of adequacy or validity. Table 4 shows that some examples of evaluation comprehension questions.

Table 4. Example of evaluation comprehension question

\begin{tabular}{|c|c|c|c|}
\hline No & Questions & Features of Descriptor & Unit \\
\hline 1 & What kind of texts is given above? & Judgment of Appropriateness & Chapter 1 \\
\hline 2 & What do you think the poem "Dreams" is about? & Judgment of Appropriateness & Chapter 7 \\
\hline 3 & What lesson did you learn from this story? & Judgment of Acceptability & Chapter 8 \\
\hline 4 & $\begin{array}{l}\text { Do you think bullying is a serious issue in } \\
\text { your school? Give reasons to support your opinion. }\end{array}$ & Judgment Fact and Opinion & Chapter 8 \\
\hline 5 & From this article, can you figure out & Judgment Reality of Fantasy & Chapter 8 \\
\hline
\end{tabular}




\begin{tabular}{llll}
\hline No & \multicolumn{1}{c}{ Questions } & Features of Descriptor & Unit \\
\hline $\begin{array}{l}\text { President Sukarno's hopes and dreams for } \\
\text { the world? Explain. }\end{array}$ & & \\
\hline
\end{tabular}

There is only 16 reading comprehension constructed in the level of appreciation comprehension. The level of appreciation problem is a question that asks students to use their senses such as hearing or feeling. The level problem reflects higher thinking, however, not many questions of appreciation are encountered. For example reactions to the author's use of language and imagery are not found in the English Textbook Entitled "Stop Bullying Now" for XI Grade of Senior High School". Table 5 shows that some examples of appreciation comprehension questions.

Table 5. Example of appreciation comprehension question

\begin{tabular}{|c|c|c|c|}
\hline No & Questions & Features of Descriptor & Unit \\
\hline \multirow[t]{2}{*}{1} & If you had to change the lyrics of "Stand by Me" & Identification with & \multirow[t]{2}{*}{ Chapter 7} \\
\hline & Which lyrics would you change? & Character and Incidents & \\
\hline 2 & How does this song make you feel? & $\begin{array}{l}\text { Emotional Response } \\
\text { to the Content }\end{array}$ & Chapter 7 \\
\hline \multirow[t]{2}{*}{3} & Have you ever witnessed an earthquake? & Identification with & \multirow[t]{2}{*}{ Chapter 8} \\
\hline & What effect did it have on you? & Character and Incidents & \\
\hline \multirow[t]{3}{*}{4} & If you were given a chance to give a speech in & Identification with & \multirow[t]{3}{*}{ Chapter 8} \\
\hline & $\begin{array}{l}\text { front of all the presidents and prime ministers } \\
\text { of the world, what would you talk about? }\end{array}$ & Character and Incidents & \\
\hline & Discuss in details & & \\
\hline \multirow[t]{2}{*}{5} & Ki Hajar made a lot of sacrifices for his country. & Identification with & \multirow[t]{2}{*}{ Chapter 8} \\
\hline & If you were in his place, what would you do? Describe. & Character and Incidents & \\
\hline
\end{tabular}

From the data, the researcher found that literal 7 (7.45\%), reorganization $0(0 \%)$, inferential $37(39.36 \%)$, evaluation $34(36.17 \%)$ and appreciation $16(17.02 \%)$. Based on the result, the researcher found that the level is commonly used in the English Textbook Entitled "Stop Bullying Now" for the XI Grade of Senior High School" based on Barrett's taxonomy was inferential comprehension level questions. The reading comprehension questions in the book included HOTS questions because according to Barrett's Taxonomy, inferential, evaluation, and appreciation included higher levels. The HOTS questions were having $92.55 \%$ (inferential, evaluation, and appreciation) rather than literal and reorganization were only having only $7.45 \%$ from 94 questions. But the level of reading comprehension must be increased again to the level of evaluation or appreciation because the results found that the evaluation and appreciation are less than the inferential level. This book needs to improve to a higher level of thinking in order to comply with the applicable curriculum, namely developing students' abilities in higherorder thinking.

\section{Discussion}

Higher-order thinking is a learning and assessment process (Putranta \& Supahar, 2019; Sagala \& Andriani, 2019). The bloom taxonomy is used as an assessment instrument in learning and as a cognitive process dimension or a knowledge dimension model (Adesoji, 2018; Gunawan \& Palupi, 2012). The assessment in the form of effective HOTS is used to measure the level of thinking skills in students (Fadzam \& Rokhimawan, 2020; Nurmala \& Mucti, 2019). the assessment method used by schools to remember information and carry out routine questions to students will not help to improve higher-order thinking skills (Prastikawati et al., 2021). Therefore, it requires formative assessment or an effective method to determine the level of reading comprehension in students to measure high-level comprehension of reading comprehension questions such as in the assessment of comprehension levels based on Barrett's taxonomy (Kumala et al., 2020; Marshel \& Ratnawulan, 2020).

According to Barrett, the good reading comprehension question can be categories into three classifications namely ideal categories, moderate categories, and bad categories (Creed et al., 2012; Lange et al., 2021). Furthermore, all texts were involved literal, inferential, evaluation, and appreciation. In this case, can be categorized that the reading comprehension question in the book was moderately categorized because the reading comprehension question does not balance between higher-order thinking skills (HOTS) and lower-order thinking skills (LOTS). The types of reading comprehension questions can stimulate students in understanding a text (Wichadee, 2011; Yuniarti \& Radia, 2020). This means that each type of question has a very important role in helping teachers develop students' reading comprehension skills (Harta et al., 2020; Ichsan et al., 2019). Therefore, 
the low level of understanding and the high level of understanding in reading must be ideal and balanced. Indeed, there is no suggestion for all questions at a high level but students need to develop critical thinking skills with higher-order thinking in the question of reading comprehension (Ani Rahmawati, Nur Lailatin Nisfah, 2019; Pratama \& Retnawati, 2018). The researcher concluded that the five types of comprehension skills in students' English books were not sufficiently represented.

\section{CONCLUSION}

The level of reading comprehension in the book should be coupled with the five levels of reading comprehension questions based on Barrett's taxonomy. Each level of reading comprehension has a very important role to play in helping teachers develop student skills. Therefore it is necessary to specifically design reading comprehension questions that consist of sub-skills, reading levels, and the number of questions at each level. Barrett's taxonomy can be used to help teachers develop reading comprehension questions at every level. By paying attention to a problem regarding the development of HOTS, teachers should practice and improve the design of questions at the level of reading comprehension in English books. The number of questions must cover the five levels of reading comprehension questions based on Barrett's Taxonomy. Besides, at the level of evaluation and appreciation, there should be more to make it fit with the national curriculum.

\section{REFERENCES}

Adadan, E., \& Oner, D. (2018). Examining preservice teachers' reflective thinking skills in the context of webbased portfolios: the role of metacognitive awareness. Australian Journal of Teacher Education, 43(11), 2650. https://doi.org/10.14221/ajte.2018v43n11.2

Adesoji, F. A. (2018). Bloom Taxonomy Of Educational Objectives And The Modification Of Cognitive Levels. Advances in Social Sciences Research Journal, 5(5). https://doi.org/10.14738/assrj.55.4233

Ani Rahmawati, Nur Lailatin Nisfah, S. K. (2019). The Capability Analysis of High Order Thinking Skills (HOTS) on Dynamic Electricity Material in Junior High School. JPPPF: Jurnal Penelitian Dan Pengembangan Pendidikan Fisika, 5(3). https://doi.org/10.21009/1.05211

Arsy, H. I., Prasetyo, A. P. B., \& Subali, B. (2020). Predict-Observe-Explain Strategy with Group Investigation Effect on Students ' Critical Thinking Skills and Learning Achievement. Journal of Primary Education, 9(1), 75-83. https://doi.org/10.15294/jpe.v9i1.29109

Aufa, M. N., Rusmansyah, R., Hasbie, M., Jaidie, A., \& Yunita, A. (2021). The Effect of Using e-module Model Problem-Based Learning (PBL) Based on Wetland Environment on Critical Thinking Skills and Environmental Care Attitudes. Jurnal Penelitian Pendidikan IPA, 7(3), 401-407. https://doi.org/10.29303/jppipa.v7i3.732

Cahya, I. D., Sutarsyah, C., \& Suparman, U. (2020). The evaluation of English textbook entitled 'Stop bullying now.' Unila Journal English Teaching, 9(1). http://jurnal.fkip.unila.ac.id/index.php/123/article/view/20661

Christianti, M. (2013). Membaca dan Menulis Permulaan Untuk Anak Usia Dini. Jurnal Pendidikan Anak, 2(2). https://doi.org/10.21831/jpa.v2i2.3042

Creed, P. A., Conlon, E. G., \& Zimmer-Gembeck, M. J. (2012). Career barriers and reading ability as correlates of career aspirations and expectations of parents and their children. Journal of Vocational Behavior, 70(2). https://doi.org/10.1016/j.jvb.2006.11.001

Crismono, P. C. (2017). Pengaruh Outdoor Learning Terhadap Kemampuan Berpikir Kritis Matematis Siswa The Influence Of Outdoor Learning On The Mathematical Critical Thinking Skills Of Students. Junal Pendidikan Matematika Dan Sains, 4(2), 106-113. https://doi.org/10.21831/jpms.v5i2.15482

Darnis. (2018). Aplikasi Montessori Dalam Pembelajaran Membaca, Menulis Dan Berhitung Tingkat Permulaan Bagi Anak Usia Dini. Jurnal Caksana: Pendidikan Anak Usia Dini, 1(1). https://doi.org/10.31326/jcpaud.v1i01.3

Din, M. (2020). Evaluating university students' critical thinking ability as reflected in their critical reading skill: A study at bachelor level in Pakistan. Thinking Skills and Creativity, 35. https://doi.org/10.1016/j.tsc.2020.100627

Fadzam, I. A., \& Rokhimawan, M. A. (2020). Analisis Materi IPA Kelas IV Tema Indahnya Kebersamaan Dengan HOTS. Jurnal Ilmiah Didaktika: Media Ilmiah Pendidikan Dan Pengajaran, 21(1). https://doi.org/10.22373/jid.v21i1.5970

Fathiara, A., Badarudin, B., \& Muslim, A. H. (2019). Meningkatkan Keterampilan Berpikir Kritis Dan Gemar Membaca Peserta Didik Melalui Model Predict Observe Explain Berbasis Literasi. Muallimuna: Jurnal Madrasah Ibtidaiyah, 4(2), 92-101. https://doi.org/10.31602/muallimuna.v4i2.1863

Gunawan, I., \& Palupi, A. R. (2012). Taksonomi Bloom - Revisi Ranah Kognitif: Kerangka Landasan Untuk 
Pembelajaran, Pengajaran, Dan Penilaian. Premiere Educandum: Jurnal Pendidikan Dasar Dan Pembelajaran, 2(2). https://doi.org/10.25273/pe.v2i02.50

Halawa, N., Ramadhan, S., \& Gani, E. (2020). Kontribusi Minat Baca Terhadap Kemampuan Membaca Pemahaman Siswa. Jurnal Edukasi Khatulistiwa, 3(1), 27. https://doi.org/10.26418/ekha.v2i2.32786

Harta, J., Rasuh, N. T., \& Seriang, A. (2020). Using HOTS-Based Chemistry National Exam Questions to Map the Analytical Abilities of Senior High School Students. Journal of Science Learning, 3(3), 143-148. https://doi.org/10.17509/jsl.v3i3.22387

Hashimoto, T., Hayashi, Y., \& Seta, K. (2019). Metacognitive Inference Activity Support by Visualizing EyeMovement Graph During Critical Reading. Procedia Computer Science, 159. https://doi.org/10.1016/j.procs.2019.09.372

Herliana, S., \& Anugraheni, I. (2020). Pengembangan Media Pembelajaran Kereta Membaca Berbasis Kontekstual Learning Siswa Sekolah Dasar. Jurnal Basicedu, 4(2), 314-326. https://doi.org/10.31004/basicedu.v4i2.346

Hewi, L., \& Shaleh, M. (2020). Refleksi Hasil PISA (The Programme For International Student Assesment): Upaya Perbaikan Bertumpu Pada Pendidikan Anak Usia Dini). Jurnal Golden Age, 4(1). https://ejournal.hamzanwadi.ac.id/index.php/jga/article/view/2018

Ichsan, I. Z., Sigit, D. V., Miarsyah, M., Ali, A., Arif, W. P., \& Prayitno, T. A. (2019). HOTS-AEP: Higher-order thinking skills from elementary to master students in environmental learning. European Journal of Educational Research, 8(4), 935-942. https://doi.org/10.12973/eu-jer.8.4.935

Kembara, Rozak, \& Hadian. (2018). Research-based Lectures to Improve Students' 4C (Communication, Collaboration, Critical Thinking, and Creativity) Skills. Proceedings of the Second Conference on Language, Literature, Education, and Culture (ICOLLITE), 1(1). https://doi.org/10.2991/icollite18.2019.50, . 20019.11.

Kumala, F. N., Setiawan, D. A., \& Shaleha, P. R. (2020). Contextual-Based Animal Encyclopedia: HOTS on Elementary School's Students. 2nd International Conference on Education and Social Science Research (ICESRE 2019) Contextual-Based, 417(Icesre 2019), 132-137. https://doi.org/10.2991/assehr.k.200318.025

Laily, I. F., \& Naqiyyah, M. (2014). Kontribusi Penerapan Pendidikan Karakter (Gemar Membaca) Terhadap Keterampilan Berbahasa Siswa Pada Mata Pelajaran Bahasa Indonesia Kelas V Mi Darul Hikam Cirebon. Al Ibtida: Jurnal Pendidikan Guru MI, 1(2). https://doi.org/10.24235/al.ibtida.snj.v1i2.347

Lange, J., Heerdink, M. W., \& Kleef, G. A. van. (2021). Reading emotions, reading people: Emotion perception and inferences drawn from perceived emotions. Current Opinion in Psychology, 43. https://doi.org/10.1016/j.copsyc.2021.06.008

Le, T. T. H., Tran, T., Trinh, T. P. T., Nguyen, C. T., Nguyen, T. P. T., Vuong, T. T., Vu, T. H., Bui, D. Q., Vuong, H. M., Hoang, P. H., Nguyen, M. H., Ho, M. T., \& Vuong, Q. H. (2019). Reading habits, socioeconomic conditions, occupational aspiration and academic achievement in Vietnamese junior high school students. Sustainability (Switzerland), 11(18), 1-29. https://doi.org/10.3390/su11185113

Majid, M. S. Z. B. A., Ali, M. M. B. A., Rahim, A. A. B. A., \& Khamis, N. Y. B. (2012). The Development of Technical English Multimedia Interactive Module to Enhance Student Centered Learning (SCL). Procedia - Social and Behavioral Sciences, 67, 345-348. https://doi.org/10.1016/j.sbspro.2012.11.337

Marshel, J., \& Ratnawulan. (2020). Analysis of Students Worksheet (LKPD) integrated science with the theme of the motion in life using integrated connected type 21 st century learning. Journal of Physics: Conference Series, 1481(1). https://doi.org/10.1088/1742-6596/1481/1/012046

McNamara, J., Sweetman, S., Connors, P., Lofgren, I., \& Greene, G. (2020). Using Interactive Nutrition Modules to Increase Critical Thinking Skills in College Courses. Journal of Nutrition Education and Behavior, 5(4). https://doi.org/10.1016/j.jneb.2019.06.007

Moghadam, Z. B., Narafshan, M. H., \& Tajadini, M. (2021). Development of a Critical Self in the Language Reading Classroom: An examination of Learners' L2 Self. Thinking Skills and Creativity, 3. https://doi.org/10.1016/j.tsc.2021.100944

Mutakinati, \& Anwari. (2018). Analysis Of Students ' Critical Thinking Skill Of Middle School Through Stem Education Project-Based Learning. Jurnal Pendidikan IPA Indonesia, 7(1), 54-65. https://doi.org/10.15294/jpii.v7i1.10495

Mutakinati, L., Anwari, I., \& Yoshisuke, K. (2018). Analysis of students' critical thinking skill of middle school through stem education project-based learning. Jurnal Pendidikan IPA Indonesia, 7(1), 54-65. https://doi.org/10.15294/jpii.v7i1.10495

Nugrahanto, S., \& Zuchdi, D. (2019). Indonesia PISA Result and Impact on The Reading Learning Program in Indonesia. International Conference on Interdisciplinary Language, Literature and Education (ICILLE 2018), 297(0), 373-377. https://doi.org/10.2991/icille-18.2019.77

Nurmala, \& Mucti, A. (2019). Efektivitas Penggunaan Lkm Berbasis Hots (Higher Order Thinking Skills) 
Terhadap Hasil Belajar Mahasiswa Pendidikan Matematika. Journal of Hanoi Math, 2(2). https://doi.org/10.30862/jhm.v2i2.67

Pakpahan, S. F., Sartika, I. D., \& Purba, Srilasima Pakpahan, E. S. (2021). An Analysis Of The Activities In English Textbook (2017 Revise Edition) Of 11" Grade Senior High School Entitled "Stop Bullying Now" Published By Kemendikbud. Jurnal Ilmu Sosial Dan Pendidikan, 5(1). https://doi.org/10.36312/jisip.v5i1.1752

Pramesti, F. (2018). Analisis Faktor-Faktor Penghambat Membaca Permulaan pada Siswa Kelas 1 SD. Jurnal Ilmiah Sekolah Dasar, 2(3), 283-289. https://doi.org/10.23887/jisd.v2i3.16144

Prastikawati, E. F., Wiyaka, W., \& Budiman, T. C. S. (2021). Pelatihan Penyusunan Soal Bahasa Inggris Berbasis HOTS bagi Guru Bahasa Inggris SMP. Jurnal Pengabdian Masyarakat, 6(1). https://doi.org/10.30653/002.202161.761

Pratama, G. S., \& Retnawati, H. (2018). Urgency of Higher Order Thinking Skills (HOTS) Content Analysis in Mathematics Textbook. Journal of Physics: Conference Series, 1097(1). https://doi.org/10.1088/17426596/1097/1/012147

Purwanita, Y., Riyanto, Y., \& Suyanto, T. (2019). The Influence of Multimedia Assisted Inquiry Learning Methods on My Heroes Theme of Critical Thinking Skills and Learning Outcomes of Class IV Students ofElementary School. International Journal of Scientific and Research Publications (IJSRP), 9(7), p9169. https://doi.org/10.29322/ijsrp.9.07.2019.p9169

Putranta, H., \& Supahar. (2019). Synthesis of the Cognitive Aspects' Science Literacy and Higher Order Thinking Skills (HOTS) in Chapter Momentum and Impulse. Journal of Physics: Conference Series, 1397(1). https://doi.org/10.1088/1742-6596/1397/1/012014

Sagala, P. N., \& Andriani, A. (2019). Development of Higher-Order Thinking Skills (HOTS) Questions of Probability Theory Subject Based on Bloom's Taxonomy. Journal of Physics: Conference Series, 1188(1). https://doi.org/10.1088/1742-6596/1188/1/012025

Silberman, D., Carpenter, R., Takemoto, J. K., \& Coyne, L. (2021). The impact of team-based learning on the critical thinking skills of pharmacy students. Currents in Pharmacy Teaching and Learning, 13(2), 116-121. https://doi.org/10.1016/j.cptl.2020.09.008

Tanudjaya, C. P., \& Doorman, M. (2020). Examining higher order thinking in Indonesian lower secondary mathematics classrooms. Journal on Mathematics Education, 11(2), 277-300. https://doi.org/10.22342/jme.11.2.11000.277-300

Turan, M. B., \& Koç, K. (2018). The impact of self-directed learning readiness on critical thinking and selfefficacy among the students of the school of physical education and sports. International Journal of Higher Education, 7(6), 98-105. https://doi.org/10.5430/ijhe.v7n6p98

Wichadee, S. (2011). Developing The Self-Directed Learning Instructional Model To Enhance English Reading Ability And Self-Directed Learning Of Undergraduate Students. Journal of College Teaching \& Learning (TLC), 8(12), 43. https://doi.org/10.19030/tlc.v8i12.6620

Widyaningrum, H. K., \& Hasanudin, C. (2019). Kajian Kesulitan Belajar Membaca Menulis Permulaan (MMP) di Sekolah Dasar [Study of Difficulty Learning to Read Beginning Writing (MMP) in Primary School]. Pedagogia: Jurnal Pendidikan, 8(2), 189-200. https://doi.org/10.21070/pedagogia.v8i2.2219

Yuniarti, A., \& Radia, E. H. (2020). Development of Comic Mathematics Teaching Materials on Flat- Building Material to Increase Reading Interest in Class IV Elementary School Students. Journal of Education Technology, 4, 415-423. https://doi.org/10.23887/jet.v4i4.30034

Yunita, Y., Fitri, F., \& Zulfahita, Z. (2017). Peningkatan Keterampilan Membaca Ekstensif Menggunakan Model Pembelajaran Reciprocal Teaching pada Siswa Kelas VIII D MTs Negeri Singkawang Tahun Ajaran 2016/2017. JP-BSI (Jurnal Pendidikan Bahasa Dan Sastra Indonesia), 2(1), 12-17. https://doi.org/10.26737/jp-bsi.v2i1.231 